Faculty of Education

Te Kura Toi Tangata

Waikato Journal of Education

Te Hautaka Mātauranga o Waikato

Volume 16, Issue 2: 2011 


\section{WAIKATO JOURNAL OF EDUCATION TE HAUTAKA MĀTAURANGA O WAIKATO}

\section{Editors:}

Jane Strachan

Noeline Wright

\author{
Editorial Board: \\ Beverley Bell \\ Bronwen Cowie \\ Deborah Fraser \\ Margie Hohepa \\ Sally Peters \\ Noeline Wright
}

\author{
Margaret Carr \\ Rosemary DeLuca \\ Richard Hill \\ Judy Moreland \\ Clive Pope
}

Waikato Journal of Education is a refereed journal, published annually, based in the Faculty of Education, The University of Waikato, Hamilton, New Zealand. It publishes articles in the broad field of education. For further information visit the WJE website http://edlinked.soe.waikato.ac.nz/research/journal/index.php?id=8

Correspondence and articles for review should be addressed to: Research Manager, Wilf Malcolm Institute of Educational Research, Faculty of Education, The University of Waikato, Private Bag 3105, Hamilton, 3240, New Zealand. Email: wmier@waikato.ac.nz

Business correspondence: Orders, subscription payments and other enquiries should be sent to the Administrator, Waikato Journal of Education, Wilf Malcolm Institute of Educational Research, Faculty of Education, The University of Waikato, Private Bag 3105, Hamilton, 3240, New Zealand, Email: wmier@waikato.ac.nz

Subscriptions: Within NZ \$40; Overseas NZ \$50

Copyright: (C) Faculty of Education, The University of Waikato

Publisher: $\quad$ Faculty of Education, The University of Waikato

Cover design: Donn Ratana

Printed by: Waikato Print

\section{Call for papers}

The Waikato Journal of Education provides an avenue of publication for quality articles on education. This peer-reviewed journal welcomes a range of topics including interdisciplinary, philosophical and applied research approaches.

Submissions are now invited for consideration for publication in the November 2012 issue. Please submit an electronic copy and a separate page with author/s contact details by 30 April 2012 to WMIER Research Manager, Carolyn Jones (cjjones@waikato.ac.nz), Faculty of Education, University of Waikato, Private Bag 3105, Hamilton 3240, New Zealand. 


\section{Waikato Journal of Education}

\section{Te Hautaka Mātauranga o Waikato}

Volume 16, Issue 2: 2011

\section{Special Edition: A teacher education partnership between the Solomon Islands and New Zealand}

Editorial

The Solomon Islands School of Education Partnership: Aspirations, context and design in educational change

Clive McGee and Patricia Rodie

Partnership experiences in developing the Preparation for Tertiary Learning course in the Teachers in Training programme

Roselyn Maneipuri, Immaculate Runialo and Noeline Wright

Making sense of health education in the Solomon Islands

Kirsten Petrie and Mark Tehe

The Solomon Islands mathematics: Pedagogy in transition?

Nigel Calder, John Beuka and Calvin Ngatulu

Taking ownership: The story of a successful partnership for change in a Pacific Island science teacher education setting

Richard Edwards, Solomon Pita and James Porakari

Funds of knowledge: Developing a Diploma in Teaching in Early Childhood Education in the Solomon Islands

Janette Kelly, Joanna Daiwo and Viola Malasa

Weaving a "Hybrid Mat": Samoa meets the Solomons

Barbara Whyte

Sustaining organisational change: Teacher education in the Solomon Islands Jane Strachan, Susanne Maezama and Janine Simi

Exploring factors that influence school planning in community high schools in the Solomon Islands: Principals' perspectives

Samuel Aruhu and David Giles

Experiences of being a leader in Choiseul Province: Opening principals' and deputy principals' contexts of leadership

John Sisiolo and David Giles

Book review 
Waikato Journal of Education

Te Hautaka Mātauranga o Waikato

Volume 16 Issue 2: 2011

\title{
Partnership experiences in developing the Preparation for Tertiary Learning course in the Teachers in Training programme
}

\author{
Roselyn Maneipuri and Immaculate Runialo \\ School of Education \\ Solomon Islands College of Higher Education \\ Noeline Wright \\ Faculty of Education \\ University of Waikato
}

\begin{abstract}
This article is a collection of three partnership voices: Roselyn Maneipuri, Immaculate Runialo and Noeline Wright. The first two, lecturers in the Arts and Languages Department at the School of Education (SOE), Honiara, Solomon Islands, found themselves working with a New Zealander who was tasked with helping them review and develop new courses for a new cohort of teacher education students. The three had never met before, but within about three weeks had to build a professional relationship, build some contextual understanding, establish what elements the course needed, and develop it in time for Roselyn and Immaculate to teach the first cohort of students (currently teaching in schools but without any teacher education background), who were due to arrive in less than three months' time.
\end{abstract}

\section{Keywords}

Partnership, pedagogy, social interaction, professional development, Solomon Islands

\section{Introduction}

We tell a story about course development-creating the introductory course for the entire cohort entering the Certificate in Teaching programme, who were already teaching in schools. Typically however, many had little education themselves beyond high school, and even less knowledge about pedagogical theories and practices. Their

Faculty of Education, University of Waikato, Hamilton, New Zealand

ISSN: 1173-6135

(pp. 21-30) 
predicament is one of the legacies of an education system frozen for three years because of civil unrest, leading to a consequent chronic lack of qualified teachers.

Our story is, we think, a hopeful one. It outlines how we tried to identify and model methods of scaffolding learning for both students and teachers, while vesting ownership of the course in Solomon Islanders themselves. We will use our three voices to demonstrate aspects of this Partnership and how those principles first advocated by Vygotsky (1978) were integrated into the very fabric of the course, thus providing Roselyn and Immaculate with pedagogical tools that updated the teacher-centric practices they said were common up to that point.

Vygotsky asserted three major themes, and social interaction is a key one of those. Essentially, Vygotsky suggested that cognitive development is linked to this social interaction process - in other words, that talking with others in the same learning situation helps unlock understanding and moves learners along a continuum, more or less from novice to proficient (in knowledge, skills, understanding). An important aspect of this relates to Vygotsky's concept of ZPD, the Zone of Proximal Development. If a learning predicament or challenge is within a learner's ZPD - that is, within the capabilities of a learner when supported by a More Knowledgeable Other (MKO) or mentor/teacher - then the likelihood of effective learning taking place is increased, because it is building on what is already known and comfortable. And even when the new learning makes the learner uncomfortable, the presence of a MKO supports the learner to manage that challenge and discomfort. This is important to remember in the light of Roselyn and Immaculate's starting point, which is outlined next.

This article is written to feature our different voices. When Roselyn and Immaculate speak, they will use mostly "we". When Noeline speaks, she will use mostly "I".

\section{Starting point: Roselyn and Immaculate}

We are lecturers in the SOE in Honiara. We had been confidently teaching our existing Communications Skills Units and English classes (underpinned by Communicative Approach principles as outlined in Mitchell, 1994) for a number of years. Within these classes, we encouraged trainee teachers to use English competently, using our own methods for teaching specific text types-letter writing, for example. While our students were taught that making mistakes was part of learning, many were scared of making mistakes and were not creative in their writing. Perhaps, inadvertently, we were training them to think in only one way, and perhaps we were teaching the way we were taught. For example, I (Roselyn) was taught not to make spoken and written errors and this has been ingrained in me for many years. It seems that I was moulding my trainees to think like I do, to speak like I do, to do things like I do. As a result, I was filled with self-doubt and had waxed dry. I was ready for change, and Noeline came at the right time.

\section{Starting point: Noeline}

My usual day job (in two parts: teaching in the pre-service secondary teacher education area, and working in a research centre ${ }^{i}$ ) was nothing like being transported to Honiara, to work in a place I'd never been, with people I'd never met, creating a course we had yet to scope, and complete it in three weeks. My background is teaching English in 
secondary schools for about 20 years, before completing my doctorate and joining the Faculty of Education as a teacher educator and educational researcher. So, developing this course was just a small challenge for those of us going to Honiara, because after I returned to New Zealand, my counterparts at the SOE would teach the first intake of the Teachers in Training ${ }^{\mathrm{ii}}$ cohort. Theirs was to be the true challenge.

However, to say there was a touch of anxiety and self-doubt on my behalf is an understatement. Not knowing what resources and tools would be available, nor knowing how I would get on with my counterparts, in no small way contributed to this self-doubt.

Once in Honiara, it was clear that up-to-date physical resources were relatively scarce (such as written texts, access to international education journals, local images and texts, as well as reliable and virus-free computer and internet services). However, Roselyn and Immaculate's openness and willingness to start a course from scratch was in abundance. They were the best resource of all, because they were also ready for change. Their practices, they said, had reached a plateau, and, given what they describe above, they wanted to invigorate their pedagogical content knowledge and practices.

\section{The TIT (Teachers in Training) programme context: Roselyn and Immaculate}

Our first cohort-those teaching both intermediate and secondary school-aged students (i.e. Years 7-13) - contained people with diverse educational backgrounds. Some had degrees in Business, Geography, Science or Agriculture, while others had diplomas and certificates as evidence of beyond school education. The bulk of this cohort, however, had left high school some years ago, but had no further education opportunities. Some had not even been in high school for long before schools were closed because of the upheaval in our country, but all were now teaching somewhere in our schools, particularly in rural and remote areas. In essence, this cohort was diverse and disparate in many ways: educationally, by age and gender, by teaching sector, and by experience. Developing an entirely new course that would both cater for all of these students and prepare them for further learning was daunting. This was the context for developing the Preparation for Tertiary Learning (PTL) course.

\section{Getting started: Noeline}

Meeting new people for the first time is often awkward. Meeting people for the first time on their patch with me occupying the role of outside "expert" was an extra dimension to this. So we talked - about what we all did, what we believed in terms of our teaching practices, and what we were proud of. It was a great place to start scaffolding our collective learning and complete our task: a course for an entire cohort that would prepare them for studying further in the programme.

As far as I could see, we had two options. One, create something that would fit right into what people already did and were familiar with, or two, create something that would serve multiple purposes. These multiple purposes included supporting Roselyn and Immaculate's pedagogical development and creativity, offering options that helped learners experience scaffolded and social learning, and imbuing the course with a selfand peer-reflective element that encouraged critical thought and independence. 
Roselyn and Immaculate had expressed some professional frustration with their current courses. They said that they did not meet what they aimed to do, which was to encourage adaptability and risk-taking in learning. Instead, their professional experiences appeared to echo Maneipuri's (2002) contention that existing curriculum had not been particularly suited for, or responsive to, times of unrest in the Solomon Islands. Roselyn and Immaculate were ready to try some new ideas and were therefore prepared to trust me, even though we had just met. This was, for me, both wonderful and terrifying. It was wonderful because their trust was a gift, and it was terrifying because of the responsibility this task entailed.

Three physical materials had to result from this course development:

- a tutor manual (outlining the practices and approaches underpinning this course and providing guidance about how to facilitate the learning activities. This was especially important for the non-specialist tutors of the course);

- a course outline for both tutors and students; and

- a book of resources linked to the tasks, assessments and activities that also drew on local contexts, so that all parts were a coherent whole.

A key undertaking was how to "build the capacity of local professionals to develop local curricula rather than relying on outside experts who will not have the required [local cultural] understanding" (Dawson, 2005, p. 3). In this case, I was yet another "outside expert" who could have easily created more frustration and more dependence, and increased the perception that the local was somehow inferior. Dawson (2005) asserted that reducing dependence on an outside expert meant supporting and encouraging use of the "local and vernacular" (p. 3).

So, we speculated together what at least one bottom line might be in order to start developing the course: that regardless of the diverse backgrounds and teaching contexts of the Teachers in Training cohort, we could be reasonably sure that few had the opportunity to explicitly understand what it means to be a learner and a teacher of learners. We could also be fairly sure that these teachers in training had few material resources to use in their classrooms. We began with those two premises, and then asked, so what should this cohort be able to know, do and understand by the time they finish this course? We decided that we wanted them to

- demonstrate some understanding of big ideas about learning, both in written and more visual text types (such as mind maps and group presentations);

- practise using these big ideas and principles in their own group problem-solving activities in a guided way (group tasks to develop social interaction);

- learn how to give and receive high quality feedback (developing effective formative and summative assessment feedback);

- learn ways of reading challenging texts (a literacy and capability-developing focus);

- learn the value of reflective practices (to develop critical self- and peerevaluation practices); and

- feel more confident as teachers who are then more able to adapt these principles to their own classrooms contexts (to foster pedagogical independence and use local resources as educative materials). 
In essence, we aimed to combine pedagogical and Vygotskian principles with metacognitive and literacy processes.

An issue in developing the course itself, however, was that Roselyn and Immaculate had teaching responsibilities to carry out while I was in Honiara. This meant they weren't always available for meetings, and they didn't always have access to online materials I was privileged to access through my university's library. At times, illness also got in the way. Sometimes, I was working alone. This meant that when we met, we would often have to talk over what I was thinking and trying to develop - to see what they thought and what they wanted included, and to balance that with the Partnership contractual requirements. Some contractual requirements to address in developing the course included aspects of gender equity, cultural/ethnic diversity, plus effective assessment and practices that included formative feedback.

We therefore decided that integrating Vygotskian principles about learning processes, with a variety of texts and text types, and content about pedagogy might be a workable approach. So, we developed a course that focused on ZPD, guided by an $\mathrm{MKO}$, and that encouraged group learning practices to foster social interaction. Activities developed throughout the course were designed to build on these elements, so that while they were working in groups, they were also examining various local and international texts about reconciliation (a key theme in the Solomon Islands), gender, assessment and learning. At the same time, they were to experience ways of structuring group work, structuring reading for meaning with challenging texts, co-operative learning strategies, and opportunities for self and peer reflection. My gut instinct was that this design would work as a structure for the Preparation for Tertiary Learning (PTL) course, but would it?

\section{The reality of teaching the PTL course: Roselyn and Immaculate}

After the first day of the PTL course, we realised that the hunger the TIT (Teachers in Training) cohort had for education was the same as ours. We began to sing the same song as Noeline. We followed what she wrote in the tutor guide for each day as our guide, and after the first week, we knew what to do; it made sense and we were enjoying teaching again. The cohort, while having limited opportunities to develop their own education, had a passion for teaching and they too enjoyed the experience, challenging though it was. The PTL course's readings, discussions and reflective activities assisted them greatly to learn more. Listed below are some of the elements that we think made the course both challenging and effective:

- a readings task modelled breaking an academic text into paragraphs with group questions designed to develop understanding collectively;

- regular opportunities for peers to reflect on others' writing — this built trust and feedback/feedforward skills;

- regular reflective writing developed their curiosity and habits of mind;

- the Six Thinking Hats approach to perspectives thinking (The de Bono Group, n.d.) helped the cohort to question what they had read or heard in a structured and safe way;

- expecting the cohort to work in different kinds of groups for different purposesthis meant they could not rely on the lecturer to do the work for them; they had to help each other solve learning problems; and 
- they learned to rely on each other as peers and equals.

This is not to say that there weren't issues. The readings Noeline provided (because we hadn't been able to access the same sorts ourselves) were challenging and tested the vocabulary and understanding of many in this cohort; they had to work outside their ZPD. On the other hand, this meant we were in the role of MKO - the More Knowledgeable Other. We provided guidance and support, modelling practices that made it easy for them to see that mistakes, wrong turns and experiments are part of learning. A big challenge was the brevity of the PTL course - we had to pack a lot into 10 days. Another was that other tutors in other curriculum areas felt that the PTL course was separate and different from their focus, and so ignored what we were trying to develop in what they were developing in their subjects. Many also did not understand the benefits of working within a clear scaffolding approach to learning, and so what the cohort learned with us was not always practised and reinforced in their curriculum classes. We think it was a missed opportunity to integrate learning.

\section{Noeline's view: From the outside looking in}

While I did not see Roselyn and Immaculate in action teaching this PTL course, I had the pleasure of visiting the SOE on further occasions for other tasks so I could find out what the experience was like. My hunch had paid off. It wasn't long before Roselyn and Immaculate had woven practices and approaches from the PTL into their other courses, making this fledgling course part of their wider professional practices. In part, this was precipitated by the cohort's evaluations of the value of the course, and in part by Roselyn and Immaculate's desire to invigorate their learners' experiences as well as develop their own practices and knowledge. This desire to take these ways of working into new contexts suggested that Roselyn and Immaculate had taken control- that this course belonged to them because they were comfortable with adapting approaches and contexts. Perhaps this was because the tutor manual was very detailed in explaining how to go about certain tasks. Maybe that helped them push their own ZPD further. While I couldn't be a physical presence as MKO, the manual helped provide that support.

Perhaps this collective development is an example of Baumgart's (1994) view that educational development must address a number of core factors in order to be successful. These core factors include emphasising quality teaching and learning, using resources and materials fit for purpose, engaging with social justice goals and putting quality assurance processes in place. From the outset, the PTL course

- explicitly modelled practices known to support learners,

- was based on respected learning theory;

- was built on the skills and abilities of the teaching staff;

- provided some just-in-time professional development; and

- included ways of seeking and giving high quality feedback: a key ingredient of quality assurance.

The social justice goal was to enhance professional independence and professional development for the teaching staff, so that they could adapt ideas for other educational contexts and courses. In other words, a social justice aim was that Roselyn and 
Immaculate became agents of their own change, once the need for the guidance of an MKO was gone.

Perhaps too, Crossley's (1994) promotion of the need for genuine collaboration (particularly in research terms) in order to reduce dependence on foreigners is indicated in this process. Perhaps by trying to keep to Vygotsky's principles of working within safe boundaries but also challenging Roselyn and Immaculate in a guided and scaffolded manner, we have succeeded in working to our strengths in this Partnership. Perhaps too, we stumbled upon a way of respecting existing knowledge and skills, while providing guided experiences that improved on and added to current practices. It also appears that this course gave Roselyn and Immaculate some experiences in changing their roles in their classes. Teasdale and Puamau (2005), for example, note that

the nineteenth and twentieth centuries, educationally speaking, can be characterised as those of the teacher. The teacher was central to educational discourse and process. This has been especially the case in the Pacific, and still is in many if not most settings. (p. 5)

Thus, helping others shift their practices to emphasise different roles for teachers and learners, while also emphasising learning how to learn, as Teasdale and Puamau (2005) advocate, and focusing on learners' practices not teachers', is a challenge in itself. What we tried to do was model a range of things simultaneously. These included group practices fostering social interaction, making metacognitive and reflective practices explicit, modelling methods for reading challenging text types, and providing experiences in which learners are knowledge creators. At the same time, teachers (including Roselyn and Immaculate) were able to learn alongside students.

What we think has happened in this Solomon Islands context appears to contrast with Mtika and Gates' (2010) contention that attempts in developing countries, using Malawi as their example, to institute learner-centred pedagogical practices is unlikely to lead to widespread change in classroom practices. Roselyn and Immaculate report that the TIT students are using principles they learned in PTL in their classrooms, while they themselves are using what they learned through the PTL in other classes they teach. Perhaps the difference may rest with the how rather than the what, for there is hope that in the Solomon Islands at least, there is the promise and evidence of pedagogical shifts.

\section{Roselyn and Immaculate's view: From the inside looking out}

The PTL course, while developed from scratch, has evolved into a more refined and fully fledged course. In 2010, for example, we identified key areas that would suit lectures, supported by subsequent tutorials in which effective learning practices are modelled. We also adapted the course to suit changing circumstances, structures and our professional experiences. Evaluations from TIT about the PTL course consistently comment on its value to them, also mentioning the challenges, such as the vocabulary levels in the articles, and the short timeframe of the course. They also appreciated the new knowledge and pedagogical practices they learned and felt this added positive value to their professional knowledge and skills.

We now think that PTL is a truly preparatory course as it is a foundation for and link to other courses. The TITs are making excellent use of these practices ${ }^{\text {iii }}$. To indicate 
how successful we think this course is, our graduate group voluntarily attend this PTL course as part of their learning, and the graduates want this course to become compulsory for them too.

Now that we have taught this course a number of times, adapted parts of it for other courses, and got consistently positive feedback from our TITs and graduates, we think this course is highly beneficial, for it encourages better writing, reading, speaking and thinking, as well as group work and evaluative and assessment practices (feedback and feedforward).

We have also learned to start with the end and work backwards, so we know what our learning goals are for our students. This was a complete change from how we had worked before. It was hard to start with, but, because it worked and we could do it and own it, we enjoyed it. Initially, we had no clue about the shape of the course, but when the structures of it emerged, we became excited, enthusiastic, and determined to try it out. Our perseverance with something new paid off.

Culture, though it may have seemed like a barrier at the start, did not deter us from working together to produce something we are proud of and which was a result of our oneness of purpose.

\section{Conclusion: Noeline}

Given the long and frustrating experiences of people in developing countries being subject to the advice of various international consultants, this particular Partnership could have easily faltered. Perhaps the time was ripe for change. Perhaps too, the tight timeframe between the genesis of the course and its actual teaching meant that there was no option but to go with it. Perhaps another influence was that this was a new course for an entirely new programme, and so there were no existing courses to rub up against.

The PTL course appears to have served multiple purposes. Firstly, the feedback suggests that the PTL course is a solid grounding for TITs to begin further study as it models ways of learning that TITs say are easily adaptable to their own classrooms. Secondly, the PTL course challenges and supports TITs' learning both within and outside of their ZPD; and, thirdly, it opens up the possibilities of using social interaction and other aspects of Vygotsky's (1978) theory as key factors in learning. It has also shown me that developing a course using Vygotsky's principles is a sound foundation, and that integrating professional development for counterparts with their own teaching practices, coupled with opportunities for peer reflection, has been both worthwhile and personally satisfying. Finally, Roselyn and Immaculate had a basis from which they could adapt, modify and transform aspects of the course for their other programmes, and also transform their own pedagogical practices from being mostly teacher-centric to more student-centred. This implies that a key goal of the Partnership - to develop and support local capacity and ownership beyond the life of the Partnership itself-is well on the way to being fulfilled.

\section{References}

Baumgart, N. (1994). Primary and secondary education for development: Key decision areas. In OECD (Eds.), Issues in education in Asia and the Pacific: An 
international perspective; Proceedings of a conference in Hiroshima (pp. 95104). Paris, France: Author.

Crossley, M. (1994). Collaborative research, ethnography and comparative and international education in the South Pacific. International Journal of Educational Development, 10(1), 37-46.

Dawson, G. (2005, July). Lessons learned from the Curriculum Reform Implementation Project. Paper presented at the 2005 National Reform Curriculum Conference, Port Moresby, Papua New Guinea. Retrieved from

http://www.pngcurriculumreform.ac.pg/research/evaluation.htm

Maneipuri, J. (2002). Solomon Islands education: Issues and challenges. In A. M. Taufe'ulungake \& C. Benson (Eds.), Tree of opportunity: Rethinking Pacific education (pp. 102-103). Suva, Fiji: Institute of Education, University of the South Pacific.

Mitchell, R. (1994). The communicative approach to language teaching: An introduction. In A. Swarbrick (Ed.), Teaching modern languages (pp. 33-42). London, England: Routledge.

Mtika, P., \& Gates, P. (2010). Developing learner-centred education among secondary trainee teachers in Malawi: The dilemma of appropriation and application. International Journal of Educational Development, 30(4), 396-404. doi:10.1016/j.ijedudev.2009.12.004

Teasdale, G. R., \& Puamau, P. (2005, July). Sustainable curriculum reform: A Pacific perspective. Paper presented at the 2005 Curriculum Reform Conference, Port Moresby, Papua New Guinea. Retrieved from

http://www.pngcurriculumreform.ac.pg/research/evaluation.htm

The de Bono Group. (n.d.). The de Bono Group-Six Thinking Hats. Retrieved February 6, 2011, from http://www.debonogroup.com/six_thinking_hats.php

Vygotsky, L. S. (1978). Mind in society: Development of higher psychological processes. Cambridge, MA: Harvard University Press.

Roselyn Maneipuri has worked at the Solomon Islands College of Higher Education, School of Education for twenty-four years. She currently coordinates the secondary teacher education programme. She teaches Communication Skills, Language Studies, Literacy Studies and Literature Studies. Her interests include writing poems, short stories, short plays, and trying out different methods of teaching. She is interested in researching 'Reading with meaning and speed: How do Solomon Islands' children learn effectively?' 


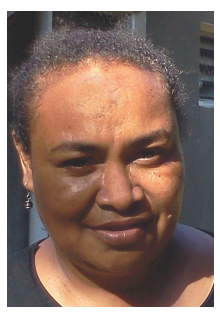

Immaculate Sarwom Runialo has worked at the Solomon Islands' School of Education for 6 years. She teaches English in both the primary and secondary teacher education programmes. Her main professional interests include curriculum development and she was involved in writing the Year 7 English Learner's book. Her previous teaching roles in Papua New Guinea include: five years teaching Business and Technical Communication in Technical and Business Colleges and ten years teaching English and Home Economic Year 7-10.

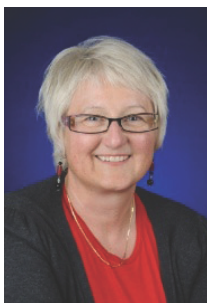

Noeline Wright currently teaches in an initial secondary teacher education programme in the Faculty of Education, The University of Waikato. She also undertakes contracted research within the Wilf Malcolm Institute of Educational Research. Her teaching and research interests include e-learning, pedagogy, secondary education, literacy and leadership. Her roles in the Partnership involved: developing the Preparation for Tertiary Learning and secondary English courses, working with the ICT committee, and facilitating some professional development on literacy across the curriculum to Partnership staff.

\footnotetext{
i
}

WMIER: Wilf Malcolm Institute of Educational Research

ii The Teachers in Training cohort programme was designed to develop the pedagogical content knowledge of teachers in classrooms who had not previously had an opportunity to engage in any teacher education. In other words, the Teachers in Training programme helps fills the teacher education gap that occurred during the civil unrest period.

iii This point is reinforced in the evidence reported in NZAID's independent review of the programme 